JURNAL RISET PENDIDIKAN MATEMATIKA

Volume 3 - Nomor 1, Mei 2016, (45 - 54)

Available online at http://journal.uny.ac.id/index.php/jrpm

\title{
PENGEMBANGAN PERANGKAT PEMBELAJARAN LIMIT BERBASIS PENDEKATAN SAINTIFIK BERORIENTASI PRESTASI BELAJAR DAN KEMAMPUAN KOMUNIKASI MATEMATIKA
}

\author{
Juliana Rakony Untayana ${ }^{1}$, Idris Harta ${ }^{2}$ \\ ${ }^{1}$ Jurusan Pendidikan Matematika, Universitas Negeri Musamus Merauke. Jalan Kamizaun Mopah \\ Lama, Kec. Merauke, Papua 99611, Indonesia \\ ${ }^{2}$ Pendidikan Matematika, Universitas Muhammadiyah Surakarta. Jalan A. Yani Tromol Pos 1, \\ Pabelan, Kartasura, Jawa Tengah 57162, Indonesia \\ * Korespondensi Penulis. Email: juliana.untajana@gmail.com \\ Received: 15 $5^{\text {th }}$ June 2016; Revised: $11^{\text {st }}$ August 2016; Accepted: $15^{\text {th }}$ August 2016
}

\begin{abstract}
Abstrak
Penelitian ini bertujuan untuk menghasilkan produk berupa perangkat pembelajaran matematika SMK menggunakan pendekatan saintifik berorientasi prestasi belajar dan kemampuan komunikasi matematika. Penelitian ini adalah penelitian pengembangan dengan model four- $D$ dari Thiagarajan. Model ini terdiri atas empat tahapan pengembangan yaitu define (pendefenisian), design (desain), develop (pengembangan) dan desseminate (penyebaran). Teknik analisis data yang digunakan adalah dengan mengelompokan data berdasarkan kualifikasi produk, kemudian dilakukan perhitungan untuk memperoleh nilai rata-rata yang dimasukkan dalam kategori penilaian skala Likert. Hasil dari penelitian ini adalah produk perangkat pembelajaran matematika SMK menggunakan pendekatan saintifik yang berorientasi pada prestasi belajar dan kemampuan komunikasi matematika siswa SMK yang terdiri atas RPP, LKS dan TPB. Setelah melalui tahapan validasi, produk RPP produk dinyatakan valid, produk perangkat memenuhi kategori sangat praktis, dan hasil tes prestasi belajar dan kemampuan komunikasi matematika memenuhi kategori efektif. Produk pengembangan yang dihasilkan telah memenuhi kriteria valid, praktis dan efektif, maka produk layak dimanfaatkan untuk pembelajaran di kelas.
\end{abstract}

Kata Kunci: Perangkat pembelajaran, pendekatan saintifik, kemampuan komunikasi matematika

\section{DEVELOPING SCIENTIFIC-APPROACH-BASED LEARNING KIT OF LIMIT ORIENTED TO MATHEMATICS LEARNING ACHIEVEMENTS AND COMMUNICATION SKILLS}

\begin{abstract}
This study is aimed at producing mathematics learning kit for SMK using the scientific approach oriented to students' mathematics learning achievements and communication skills.This research was a research and development employing the four-D model by Thiagarajan. The model consisted of four development stages, namely define, design, develop, and disseminate. The research instruments were validation sheets, practicallity sheets, and learning achievement tests. The data were analyzed by grouping the data based on the product qualification and then calculations were made to obtain mean scores classified into categories in the Likert scale assessment. The results of the study are a product in the form of mathematics learning kit for SMK using the scientific approach oriented to students' mathematics learning achievements and communication skills, consisting of lesson plans, student worksheets, and learning achievement tests. Through the product validation stage, the lesson plans are considered to be valid. The product is very practical, and the results of the mathematics learning achievement and communication skill tests show that the product is effective. The developed product is valid, practical, and effective, and is appropriate to be used in classroom.
\end{abstract}

Keywords: learning kit, scientific approach, mathematics communication skills

How to Cite: Untayana, J., \& Harta, I. (2016). Pengembangan perangkat pembelajaran limit berbasis pendekatan saintifik berorientasi prestasi belajar dan kemampuan komunikasi matematika. Jurnal Riset Pendidikan Matematika, 3(1), 45-54. doi:http://dx.doi.org/10.21831/jrpm.v3i1.9683

Permalink/ DOI: http://dx.doi.org/10.21831/jrpm.v3i1.9683 


\section{PENDAHULUAN}

Pendidikan memiliki peranan yang penting dalam masyarakat karena melalui pendidikan seseorang memiliki pengetahuan, keterampilan dan sikap sehingga dapat mengembangkan dirinya dan menjadi pribadi yang berakhlak mulia. Hal ini sesuai dengan Undang-Undang Nomor 20 Tahun 2003 tentang Sistem Pendidikan Nasional Pasal 1 yang menyatakan bahwa pendidikan adalah usaha sadar dan terencana untuk mewujudkan suasana belajar dan proses pembelajaran agar peserta didik secara aktif mengembangkan potensi dirinya untuk memiliki kekuatan spiritual keagamaan, pengendalian diri, kepribadian, akhlak mulia, serta keterampilan yang diperlukan dirinya, masyarakat, bangsa dan negara.

Perihal mengenai pendidikan berarti berbicara mengenai pembelajaran di sekolah karena melalui pembelajaran di sekolah seseorang mendapat pengetahuan. Dalam pelaksanaan suatu pembelajaran yang dilakukan di sekolah ada tujuan yang harus dicapai, tujuan tersebut merupakan sebuah prestasi belajar bagi siswa yang menempuh pendidikan. Winkel (2014, p.226) menyatakan bahwa prestasi belajar adalah suatu bukti keberhasilan belajar atau kemampuan seorang siswa dalam melakukan kegiatan belajarnya sesuai dengan bobot yang dicapainya. Berdasarkan hal tersebut maka prestasi belajar dalam pendidikan merupakan salah satu tujuan pendidikan yang perlu untuk ditingkatkan.

Fakta di lapangan menunjukkan bahwa prestasi belajar matematika para siswa di Indonesia semakin merosot. Hal ini dapat dilihat dari hasil studi PISA 3 kali yang terakhir yaitu pada tahun 2006 Indonesia berada peringkat ke 50 dari 57 peserta, tahun 2009 peringkat ke 61 dari 65 peserta, dan tahun 2012 peringkat 64 dari 65 peserta (OECD, 2014). Selain itu, daya serap siswa SMK secara nasional dalam UN terus mengalami penurunan dalam tiga tahun terakhir yang disajikan pada Tabel 1 .

Tabel 1. Daya Serap Matematika Siswa SMK secara Nasional

\begin{tabular}{lccc}
\hline & $\mathbf{2 0 1 1}$ & $\mathbf{2 0 1 2}$ & $\mathbf{2 0 1 3}$ \\
\hline Klasifikasi & B & A & D \\
Rata-rata & 7,45 & 7,60 & 5,24 \\
Tertinggi & 0,25 & 0,25 & 0,75 \\
Terendah & 10,00 & 10,00 & 10,00 \\
Standar Deviasi & 1,70 & 1,78 & 1,76 \\
\hline
\end{tabular}

BSNP (2011, 2012 dan 2013)
Hal yang sama juga dialami secara regional yaitu di daerah Yogyakarta, nilai UN siswa SMK di daerah Yogyakarta dalam 3 tahun berturut-turut mengalami penurunan. Berikut data statistik hasil UN mata pelajaran matematika SMK di Yogyakarta tiga tahun terakhir disajikan pada Tabel 2.

Tabel 2. Daya Serap Matematika Siswa SMK di Yogyakarta

\begin{tabular}{lccc}
\hline & $\mathbf{2 0 1 1}$ & $\mathbf{2 0 1 2}$ & $\mathbf{2 0 1 3}$ \\
\hline Klasifikasi & $\mathrm{B}$ & $\mathrm{B}$ & $\mathrm{C}$ \\
Rata-rata & 7,01 & 6,67 & 6,43 \\
Terendah & 1,00 & 1,00 & 1,00 \\
Tertinggi & 10,00 & 10,00 & 10,00 \\
Standar Deviasi & 2,08 & 2,23 & 2,10 \\
\hline BSNP (2011, 2012 dan 2013) & &
\end{tabular}

BSNP (2011, 2012 dan 2013)

Berdasarkan Tabel 2, dapat diperoleh bahwa prestasi belajar siswa sangat memprihatinkan dan semakin merosot sehingga perlu ditingkatkan. Keberhasilan pencapaian tujuan pembelajaran sangat bergantung pada proses pembelajaran yang dilakukan oleh guru di kelas, karena proses pembelajaran adalah proses dimana guru dan siswa berinteraksi secara langsung. Interaksi antara guru dan siswa dapat terjadi melalui komunikasi. Komunikasi adalah hal yang penting karena melalui komunikasi pengetahuan dari seseorang dapat dipindahkan kepada orang lain.

Kemampuan komunikasi dalam pembelajaran matematika merupakan salah satu kemampuan yang perlu untuk dikembangkan. Menurut Greenes \& Schulman (1996, p.159) komunikasi matematika adalah kemampuan untuk: (1) menyatakan ide matematika melalui ucapan, tulisan, demonstrasi dan melukiskan secara visual dalam tipe yang berbeda; (2) memahami, menafsirkan dan menilai ide yang disajikan dalam tulisan, lisan atau dalam bentuk visual; (3) menafsirkan dan menghubungkan bermacammacam representasi ide dan hubungannya. Senada dengan pernyataan tersebut NCTM (2000, p.348) menyatakan bahwa kemampuan komunikasi matematika perlu dibangun dalam diri siswa yang bertujuan untuk: (1) menyusun dan mengaitkan pemikiran matematika mereka melalui komunikasi; (2) mengkomunikasikan pemikiran matematika secara koheren dan jelas kepada teman-temannya, guru, dan orang lain; (3) menganalisis dan menilai pemikiran matematika dan strategi yang dipakai orang lain; serta (4) menggunakan bahasa matematika untuk mengekspresikan ide-ide matematika secara benar.

Berdasarkan pendapat-pendapat ahli tersebut terlihat bahwa kemampuan komunikasi 
matematika merupakan kemampuan yang sering kali digunakan untuk merepresentasikan dan menyelesaikan berbagai permasalahan dalam kehidupan. Jadi kemampuan komunikasi matematika merupakan hal yang penting untuk dikuasai oleh siswa.

Penjelasan mengenai kemampuan komunikasi matematika tersebut menyatakan bahwa bukan hanya sekedar ide yang diungkapkan melalui tulisan tetapi juga kemampuan siswa dalam hal menjelaskan, menggambarkan, mendengarkan, dan menanyakan ide-ide matematika secara benar. Hal tersebut senada dengan hasil studi PISA yang menunjukkan bahwa siswa Indonesia kurang terlatih dalam menyelesaikan soal-soal yang menggunakan kemampuan penalaran dan komunikasi matematika, sebab kedua kemampuan tersebut merupakan kemampuan yang diujikan dalam PISA. Hal tersebut dapat dilihat dari proporsi komponen proses yang diuji dalam studi uji PISA yang disajikan pada Tabel 3 .

Tabel 3.Proporsi Komponen Proses yang Diuji dalam Studi PISA

\begin{tabular}{llc}
\hline Komponen & \multicolumn{1}{c}{$\begin{array}{c}\text { Kemampuan yang } \\
\text { Diujikan }\end{array}$} & $\begin{array}{c}\text { Skor } \\
(\mathbf{\%})\end{array}$ \\
\hline Proses & $\begin{array}{l}\text { Mampu merumuskan masalah } \\
\text { matematika }\end{array}$ & 25 \\
& $\begin{array}{l}\text { Mampu menggunakan konsep, } \\
\text { fakta, prosedur, dan penalaran }\end{array}$ & 50 \\
& dalam matematika & \\
& $\begin{array}{l}\text { Menafsirkan, menerapkan dan } \\
\text { mengevaluasi hasil dari suatu }\end{array}$ & 25 \\
& proses matematika & \\
\hline (OECD, 2014).
\end{tabular}

Berdasarkan Tabel 3 terlihat bahwa kemampuan komunikasi dan kemampuan penalaran matematika menjadi bagian yang diujikan dalam PISA. Pada poin 1 mampu merumuskan masalah matematika dan poin 3 menafsirkan, menerapkan dan mengevaluasi hasil dari suatu proses matematika berkaitan dengan kemampuan komunikasi matematika, sedangkan poin 2 mampu menggunakan konsep, fakta, prosedur dan penalaran dalam matematika berkaitan dengan kemampuan penalaran matematika.

Berdasarkan hasil studi PISA maka terlihat bahwa kemampuan komunikasi matematika siswa di Indonesia masih rendah. Hal tersebut terjadi karena dalam pembelajaran matematika guru masih jarang meminta penjelasan kepada siswa mengenai jawaban-jawaban yang diberikan. Hal tersebut sesuai dengan pendapat Cai, Lane, \& Jakabcsin (2009, p.26) yang mengemukakan bahwa karena siswa jarang diminta untuk berargumentasi dalam pembelajaran matematika, akibatnya sangat asing bagi mereka untuk berbicara matematika. Selain itu, menurut Kusnaeni \& Retnawati (2013, p.34) penyebab lain rendahnya kemampuan komunikasi matematis karena siswa lebih banyak dituntut untuk mendengarkan penjelasan guru dan mengerjakan soal berdasarkan contoh yang diberikan guru atau algoritma tertentu, tapi siswa jarang sekali diminta mengkomunikasikan ide-idenya, baik dengan cara mengajukan pertanyaan pada guru maupun menjawab pertanyaan dari guru.

Hal yang dapat dilakukan agar kemampuan komunikasi matematika menjadi baik, maka perlu dirancang suatu pembelajaran yang dapat menstimulasi siswa untuk berkomunikasi dengan baik. Perancangan suatu pembelajaran berkaitan dengan perencanaan pembelajaran, karena perencanaan pembelajaran merupakan langkah-langkah yang dipersiapkan oleh guru sebelum melaksanakan suatu kegiatan pembelajaran. Perencanaan dapat diartikan sebagai proses penyusunan tujuan pembelajaran, materi pelajaran, penggunaan media pembelajaran, penggunaan pendekatan pembelajaran, metode pembelajaran, alokasi waktu belajar dan penilaian pembelajaran. Semua yang telah disebutkan dapat ditemukan pada perangkat pembelajaran yaitu silabus, rencana pelaksanaan pembelajaran (RPP), bahan ajar, dan lembar kerja siswa (LKS).

Perangkat pembelajaran menurut Nazarudin (2007, p.113) adalah sesuatu atau beberapa persiapan yang disusun oleh guru agar pelaksanaan dan evaluasi pembelajaran dapat dilakukan secara sistematis dan memperoleh hasil seperti yang diharapkan. Perangkat pembelajaran disusun dengan tujuan untuk memenuhi keberhasilan guru dalam pembelajaran. Guru perlu untuk memiliki dan menyiapkan perangkat pembelajaran, karena dengan perangkat pembelajaran dapat memudahkan guru dalam membantu proses fasilitasi pembelajaran.

Perangkat pembelajaran merupakan sesuatu yang sangat penting yang harus dibuat serta harus diperhatikan oleh guru, karena perangkat pembelajaran berperan penting untuk kesuksesan proses pembelajaran. Oleh sebab itu, setiap guru wajib menyusun dan memiliki perangkat pembelajaran. Hal ini senada dengan pernyataan Posamentier (2007, p.47) yang menyatakan bahwa "...., it is universally accepted a well-designed lesson plan is the main ingredient of a successful lesson". Pernyataan tersebut menunjukkan bahwa selain silabus, guru juga 
harus menyiapkan rencana pelaksanaan pembelajaran sebagai bagian utama dari kesuksesan dalam proses pembelajaran.

Selain rencana pelaksanaan pembelajaran, hal yang tak kalah pentingnya dalam pelaksanaan pembelajaran adalah ketersediaan LKS. Seorang guru yang menginginkan agar pembelajaran yang dilaksanakan dapat mengaktifkan semua siswa harus menyiapkan LKS. Dengan demikian dalam menyusun rencana pelaksanaan pembelajaran seorang guru harus melengkapinya dengan LKS. Pendapat tersebut sesuai dengan pernyataan Wilder, et al. (2011, p.94) yang menyatakan bahwa "your plan for a topic should include: ...details of relevant resources, such as textbooks, worksheets, ICT resource, webbased material etc".

Salah satu penyebab merosotnya prestasi belajar siswa adalah ketidakmampuan guru dalam menyusun perangkat pembelajaran. Hal ini sesuai dengan pernyataan Sutherland (2007, p.78) bahwa kegiatan perancangan pembelajaran sesuai kurikulum membutuhkan berbagai keterampilan yang berbeda dari sekedar keterampilan mengajar di dalam kelas. Dengan demikian untuk mencapai prestasi belajar yang tinggi diperlukan perangkat pembelajaran untuk menunjang keterlaksanaan proses pembelajaran.

Rendahnya hasil belajar siswa diduga disebabkan oleh belum maksimalnya guru dalam menggunakan pendekatan dan metode pembelajaran (Rahmawati \& Harta, 2014, p.3). Selain itu, rancangan kegiatan pembelajaran yang tertuang dalam RPP juga seharusnya menggunakan pendekatan pembelajaran yang berpusat pada siswa. Pendekatan pembelajaran yang berpusat pada siswa salah satunya adalah pendekatan ilmiah (scientific approach) atau lebih sering disebut dengan metode ilimiah atau metode saintifik.

Aragon (2007, p.1) menyatakan bahwa metode ilmiah didefinisikan sebagai: "systematic process for acquiring new knowledge that uses the basic principle of deductive (and to a lesser extent inductive) reasoning. It's considered the most rigorous way to elucidate cause and effect, as well as discover and analyze less direct relationships between agentsand their associated phenomena". Dari pernyataan tersebut dapat dipahami bahwa metode ilmiah adalah proses sistematis untuk memperoleh pengetahuan baru yang menggunakan prinsip dasar penalaran deduktif (dan pada tingkat lebih rendah induktif). Ini dianggap sebagai cara yang paling ketat untuk menjelaskan sebab dan akibat, serta menemukan dan menganalisis hubungan yang kurang langsung antara agen dan fenomena yang terkait.Dalam konteks pendidikan di Indonesia, pendekatan ilmiah menerapkan tahapan-tahapan metode ilimiah yaitu mengamati, menanya, mencoba, mengolah, menyajikan, menyimpulkan, dan mencipta untuk semua mata pelajaran. (Kemendikbud, 2013, p.203). Hal inilah yang menjadi pilar dalam pengembangan Kurikulum 2013.

Implementasi Kurikulum 2013 sangat menonjolkan pendekatan saintifik karena berpusat pada siswa. Hal ini sesuai dengan Permendikbud Nomor 65 Tahun 2013 tentang Standar Proses yang menyatakan bahwa pendekatan saintifik digunakan pada jenjang SMP dan SMA/SMK. Pendekatan saintifik sangat penting untuk dikuasai oleh setiap guru yang mengajar di SMP dan SMA/SMK. Karena melalui pendekatan saintifik pembelajaran diarahkan untuk mendorong peserta didik dalam mencari tahu dari berbagai sumber melalui observasi, dan bukan hanya diberi tahu.

Mengingat masih banyaknya permasalahan dalam pembelajaran matematika saat ini, maka perlu dilakukan perbaikan dalam penyusunan perangkat pembelajaran dengan menggunakan pendekatan saintifik, karena pendekatan ini akan memudahkan guru atau pengembang kurikulum untuk memperbaiki proses pembelajaran, yaitu dengan memecah proses ke dalam langkah-langkah atau tahapan-tahapan secara terperinci yang memuat instruksi untuk siswa melaksanakan kegiatan pembelajaran (Varelas \& Ford, 2008, p.31). Dalam pembelajaran yang menggunakan pendekatan saintifik siswa dituntut untuk lebih aktif sehingga pembelajaran yang terjadi adalah pembelajaran yang berpusat pada siswa. Adapun ketika pendekatan saintifik diterapkan dengan benar maka prestasi belajar dan kemampuan komunikasi akan mengalami peningkatan. Hal ini diduga karena adanya langkah-langkah dalam pendekatan saintifik yang meliputi mengamati, menanya, mengumpulkan informasi, mengasosiasi, dan mengkomunikasikan.

Permasalahan-permasalahan yang sedang dihadapi saat ini dapat diatasidengan melakukan penelitian yang mengembangkan perangkat pembelajaran yang meliputi RPP, bahan ajar, LKS, dan tes hasil belajar dengan menggunakan pendekatan saintifik untuk meningkatkan prestasi belajar dan kemampuan komunikasi matematika siswa. Pembelajaran yang menggunakan pendekatan saintifik diharapkan dapat mening- 
katkan prestasi belajar dan kemampuan komunikasi matematika siswa.

Eggen \& Kaucak (2012, pp.19-21) menyatakan bahwa guru harus memiliki pengetahuan profesional dan keluasan khazanah strategi mengajar. Selain itu juga guru harus memahami dan menggunakan berbagai strategi mengajar untuk mendorong perkembangan pemikiran kritis, pemecahan masalah dan ketrampilan kinerja siswa. Berdasarkan pendapat tersebut dapat disimpulkan bahwa perangkat pembelajaran adalah suatu persiapan yang disusun oleh guru berupa media dan sarana yang digunakan untuk meningkatkan keterlibatan siswa dalam pembelajaran agar pelaksanaan dan evaluasi pembelajaran dapat dilakukan secara sistematis dan memperoleh hasil seperti yang diharapkan yaitu mencapai kompetensi yang telah ditentukan.

Moon, Meyes, \& Hutchinson (2002, p.54) menyatakan "the effective teacher is very systematic in the preparation for, and execution, of each lesson". Guru yang efektif sangat sistematis dalam persiapan, dan pelaksanaan dalam setiap pembelajarannya. Ini menunjukkan bahwa kegiatan pembelajaran akan efektif apabila direncanakan dan diatur dengan baik. Hal ini senada dengan pendapat Kyriacou (2009, p.86) bahwa semua guru perlu memiliki ide yang jelas tentang pembelajaran yang ingin mereka laksanakan dan melakukan persiapan yang matang agar pembelajaran berlangsung dengan sukses. Perangkat pembelajaran merupakan sesuatu yang sangat penting yang harus dibuat serta harus diperhatikan oleh guru, karena perangkat pembelajaran berperan penting dalam kesuksesan proses pembelajaran. Oleh sebab itu, setiap guru wajib menyusun dan memiliki perangkat pembelajaran, baik berupa RPP, LKS, maupun tes prestasi belajar.

Tes Prestasi Belajar atau TPB merupakan perangkat yang digunakan untuk mengukur keberhasilan siswa dalam menguasai satu indikator atau lebih. Tes dapat dilaksanakan bila siswa telah melalui suatu proses pembelajaran. Hal ini sesuai dengan pendapat Kemp. et. al (1994, p.57) yang menyatakan bahwa tes diterapkan untuk mengukur seberapa jauh setiap peserta didik mencapai tingkat pemahaman dan kemampuan yang ditetapkan oleh setiap sasaran yang dituju. Dengan demikian Tes prestasi belajar merupakan prosedur untuk mengukur atau menilai keberhasilan siswa dalam menempuh suatu pembelajaran.

Berkaitan dengan peniaian keberhasilan siswa, penilaian yang digunakan dalam Kuriku- lum 2013 adalah penilaian otentik. Nurgiyantoro (2008, p.251) menyatakan bahwa penilaian otentik mementingkan penilaian proses dan hasil sekaligus. Dengan demikian, seluruh tampilan siswa dalam rangkaian kegiatan pembelajaran dapat dinilai secara objektif, apa adanya, dan tidak semata-mata hanya berdasarkan hasil akhir (produk) saja. Hal senada juga dikemukakan oleh Johnson, et al. (2009, p.2) yang berpendapat bahwa penilaian otentik pada dasarnya adalah penilaian performa yakni penilaian yang dilakukan untuk mengetahui pengetahuan dan keterampilan siswa selama proses pembelajaran dalam mencapai tujuan atau hasil belajar tertentu. Dengan demikian dapat disimpulkan bahwa penilaian otentik mementingkan penilaian proses sekaligus hasil.

Pendekatan yang digunakan dalam Kurikulum 2013 adalah pendekatan saintifik. Metode scientific ini memiliki karakteristik "doingscience". Metode ini memudahkan guru atau pengembang kurikulum untuk memperbaiki proses pembelajaran, yaitu dengan memecah proses ke dalam langkah-langkah atau tahapantahapan secara terperinci yang memuat instruksi untuk siswa melaksanakan kegiatan pembelajaran (Varelas and Ford, 2008, p.31).

Dyer et al (2011) menyatakan bahwa dua pertiga dari kemampuan kreativitas seseorang diperoleh melalui pendidikan, dan sisanya berasal dari genetik. Kemampuan kreativitas diperoleh melalui mengamati (observing), menanya (questioning), mencoba (experimenting), menalar (associating), dan membentuk jaringan (networking). Oleh sebab itu, pendekatan saintifik sangat baik untuk diterapkan dalam pembelajaran. Hal lain juga disampaikan oleh Daryanto (2014, p.55) bahwa pembelajaran berbasis pendekatan ilimiah itu lebih efektif dibandingkan dengan pembelajaran tradisional.

Berdasarkan pernyataan sebelumnya maka dapat disimpulkan bahwa pendekatan saintifik mempunyai peranan penting dalam pembelajaran. Hal ini disebabkan karena pembelajaran dengan menggunakan pendekatan saintifik tidak hanya memberikan pengetahuan saja tetapi siswa juga akan memperoleh keterampilan dan sikap. Selain itu, sebelumnya juga telah diuraikan bahwa pendekatan saintifik dapat memfasilitasi siswa untuk mengembangkan kemampuan komunikasi matematikanya.

Komunikasi sebagai cara berbagi pesan atau sikap yang menghasilkan tingkat pemahaman antara pengirim dan penerima. Di kelas komunikasi melibatkan pertukaran informasi 
secara terus-menerus sebagai proses yang melibatkan sejumlah orang yang menerima dan mengirim pesan. Salah satu cara untuk menganalisis komunikasi adalah dengan cara mengkategorikannya dalam kemampuan, yaitu: kemampuan bahasa, ketrampilan sosial, dan ketrampilan kognitif.

Selain itu, menurut Brodie (2010, p.7) "mathematics reasoning assumes mathematical communication. Communication is a integral part of procces reasoning". Maknanya adalah bahwa penalaran matematika diasumsikan melalui komunikasi matematis. Dapat dikatakan bahwa komunikasi merupakan bagian yang tak terpisahkan dari proses penalaran.

Salah satu standar proses menurut NCTM adalah komunikasi matematika yang diuraikan oleh Cooke \& Buchholz (2005, p.365) sebagai berikut. The communication standard highlight the importance of young children communication their mathematical thinking coherently to peers and teachers. This standard also state that young children should use math language to express mathematical ideas (Baroody, 2000; Ginsburg, Inoue, \& Seo, 1999; NCTM, 2000; Rubenstein \& Thompson, 2002; Whitin \&Whitin, 2003).

Makna dari pernyataan tersebut adalah standar komunikasi menyoroti pentingnya berpikir matematis yang koheren dan komunikasi siswa bagi sesama teman dan guru. Standar ini juga menyatakan bahwa siswa harus menggunakan bahasa matematika untuk mengekspresikan ide-ide matematis. Selain itu juga guru perlu mendorong kemampuan komunikasi siswa pada setiap pembelajaran di kelas. Hal tersebut senada dengan pernyataan Pugalee (2001, p.3) yang mengatakan bahwa siswa perlu dibiasakan dalam pembelajaran untuk memberikan argumen atas setiap jawabannya serta memberikan tanggapan atas jawaban yang diberikan oleh orang lain, sehingga apa yang sedang dipelajari menjadi lebih bermakna baginya.

Terkait dengan permasalahan-permasalahan yang telah dikemukankan berikut kajian teorinya, penelitian ini bertujuan untuk menghasilkan produk berupa perangkat pembelajaran matematika SMK menggunakan pendekatan saintifik berorientasi prestasi belajar dan kemampuan komunikasi matematika siswa.

\section{METODE}

Jenis penelitian ini adalah penelitian pengembangan atau development research. Penelitian ini bertujuan untuk mengembangkan dan menerapkan pembelajaran matematika SMK dengan menggunakan pendekatan saintifik. Penelitian ini difokuskan pada pengembangan perangkat pembelajaran. Perangkat pembelajaran yang dikembangkan meliputi Rencana Pelaksanaan Pembelajaran (RPP), Lembar Kegiatan Siswa (LKS) dan Tes Prestasi Belajar (TPB). Model pengembangan yang digunakan dalam penelitian ini adalah model 4-D yang dikembangkan oleh Thiagarajan, Semmel, \& Semmel (1974), dengan kriteria penilaian kualitas produk menggunakan kriteria dari Nieven (1999), meliputi aspek kevalidan, kepraktisan, dan keefektifan. Model ini terdiri atas empat tahapan pengembangan, yaitu define (pendefenisian), design (desain), develop (pengembangan), dan desseminate (penyebaran). Penelitian pengembangan dimulai dengan melakukan validasi instrumen oleh para ahli, uji terbatas dan uji lapangan.

Uji coba produk bertujuan untuk mengetahui kelayakan dari produk yang dikembangkan yaitu mencakup kepraktisan dan keefektifan. Sebelum dilakukan uji coba lapangan RPP, LKS dan TPB divalidasi oleh ahli kemudian dianalisis. Subjek uji coba adalah 2 orang guru mitra dan siswa kelas $X$ akomodasi perhotelan SMK Negeri 6 Yogyakarta. Data dalam penelitian ini berupa data validasi ahli mengenai perangkat dan instrumen yang dikembangkan, data keterlaksanaan pembelajaran, data penilaian guru, data penilaian siswa, data tes prestasi belajar, dan data tes kemampuan komunikasi matematika.

Instrumen yang digunakan untuk mengumpulkan data pada penelitian ini dapat diklasifikasi menjadi tiga macam yang masingmasing digunakan untuk memenuhi kerteria kevalidan, kepraktisan, dan keefektifan. Instrumen untuk mengukur kevalidan yaitu lembar validasi RPP, LKS, dan TPB. Instrumen untuk mengukur kepraktisan yaitu lembar penilaian guru, lembar penilaian siswa, dan lembar observasi keterlaksanaan pembelajaran. Instrumen untuk mengukur keefektifan yaitu tes prestasi belajar dan tes kemampuan komunikasi matematika

Analisis data dilakukan untuk mendapatkan perangkat pembelajaran yang memenuhi syarat valid, praktis, dan efektif. Jika syarat ini dipenuhi maka didapatkan produk yang berkualitas. Adapun langkah-langkah yang digunakan untuk menetukan kriteria kualitas terhadap produk yang dikembangkan meliputi: (a) data berupa skor penilaian ahli/praktisi yang diperoleh melalui lembar validasi dijumlahkan. (b) total skor aktual yang diperoleh kemudian dikonver- 


\section{Jurnal Riset Pendidikan Matematika, 3 (1), Mei 2016 - 51}

Juliana Rakony Untayana, Idris Harta

sikan menjadi data kualitatif skala lima dengan mengacu pada rumus konversi seperti pada Tabel 4.

Tabel 4.Kategori Kualitatif Interpretasi Data

\begin{tabular}{ccc}
\hline No & RentangSkorKuantitatif & Nilai \\
\hline 1 & $(\mathrm{M}+1,50 \mathrm{~s})<\bar{x}$ & $\mathrm{~A}$ \\
2 & $(\mathrm{M}+0,50 \mathrm{~s})<\bar{x} \leq(\mathrm{M}+1,50 \mathrm{~s})$ & $\mathrm{B}$ \\
3 & $(\mathrm{M}-0,50 \mathrm{~s})<\bar{x} \leq(\mathrm{M}+0,50 \mathrm{~s})$ & $\mathrm{C}$ \\
4 & $(\mathrm{M}-1,50 \mathrm{~s})<\bar{x} \leq(\mathrm{M}-0,50 \mathrm{~s})$ & $\mathrm{D}$ \\
5 & $\bar{x} \leq(\mathrm{M}-1,50 \mathrm{~s})$ & $\mathrm{E}$ \\
\hline
\end{tabular}

(Azwar, 2009, p.163)

Keterangan:

$\bar{x}=$ Rata-rata skor aktual

$\mathrm{M}=$ Rata-rata skor ideal $=\frac{1}{2}$ (skor maksimum + skor minimum)

$\mathrm{s}=$ Simpanganbaku ideal $=\frac{1}{6}($ skor maksimum skor minimum)

Perangkat pembelajaran dikatakan valid jika memenuhi kategori minimal $\mathrm{B}$, kategori kualitatif yang digunakan pada lembar validasi, lembar penilaian guru, dan lembar penilaian siswa adalah sangat praktis/sangat valid (A), praktis/valid (B), cukup praktis/cukup valid (C), Kurang praktis/kurang valid (D), dan sangat kurang praktis/sangat kurang valid (E).

\section{HASIL DAN PEMBAHASAN}

\section{Hasil}

Pengembangan perangkat pembelajaran dengan menggunakan model pengembangan 4$\mathrm{D}$ dimulai dengan tahap pendefinisian (define). Pada tahap pendefinisian akan dideskripsikan lima tahap kegiatan yang dilakukan yaitu analisis awal-akhir, analisis siswa, analisis konsep, analisis tugas dan spesifikasi tujuan pembelajaran. Tahap selanjutnya yang harus dilakukan setelah tahap pendefinisian adalah adalah tahap perancangan. Pada tahap perancangan ini terdiri atas tiga langkah, yaitu pemilihan media, pemilihan format, dan perancangan awal. Tahap perancangan ini menghasilkan prototipe produk yang disebut dengan draft 1.

Selanjutnya dilakukan validasi oleh ahli dan praktisi untuk menilai draf-1. Validasi juga bertujuan untuk menggali komentar dan saran baik lisan maupun tulisan dengan cara berdiskusi tentang perangkat pembelajaran yang dikembangkan. Kegiatan validasi dilakukan dengan cara memberikan naskah perangkat pembelajaran (RPP, LKS dan THB) beserta lembar validasi kepada dua validator ahli. Adapun hasil penilai ahli terhadap perangkat yang dikembangkan disajikan pada Tabel 5.

Tabel 5. Skor Hasil Validasi Perangkat Pembelajaran

\begin{tabular}{cccc}
\hline Validator & RPP & LKS & THB \\
\hline 1 & 140 & 72 & 84 \\
2 & 156 & 81 & 95 \\
Skor Total & 296 & 153 & 179 \\
Rata-rata & 148 & 76,5 & 89,5 \\
\hline
\end{tabular}

Berdasarkan tabel 5 dapat dilihat bahwa rata-rata skor hasil validasi ahli untuk RPP adalah 148 dengan rentang skor $\bar{x}>116,67$. Ratarata skor untuk LKS adalah 76,5 dengan rentang skor $\bar{x}>60$ dan rata-rata skor untuk TPB adalah 89,5 dengan dengan rentang skor $\bar{x}>70$.

Setelah melakukan revisi yang sesuai dengan saran dan masukan validator, maka produk perangkat pembelajaran yang dihasilkan (RPP, LKS dan TPB) dinyatakan telah mencapai kriteria valid berdasarkan hasil validasi beberapa ahli. Kevalidan perangkat pembelajaran didukung oleh penyusunan perangkat yang sesuai dengan Kurikulum 2013.

Setelah perangkat yang dikembangkan divalidasi dan dinyatakan valid, maka tahapan berikutnya yaitu uji coba lapangan. Pelaksanaan uji coba lapangan bertujuan untuk mengukur kepraktisan dan keefektifan perangkat yang dikembangkan melalui data yang diperoleh. Data kepraktisan meliputi data penilaian guru, penilaian siswa dan hasil observasi keterlaksanaan perangkat pembelajaran, sedangkan data keefektifan meliputi data tes hasil belajar. Data penilaian guru mengenai kepraktisan perangkat disajikan pada Tabel 6 .

Tabel 6. Data Penilaian Guru Mengenai Kepraktisan Perangkat Pembelajaran

\begin{tabular}{cccc}
\hline Penilaian Guru & RPP & LKS & TPB \\
\hline 1 & 29 & 26 & 25 \\
2 & 29 & 28 & 25 \\
Total Skor & 58 & 54 & 50 \\
Rata-rata & 29 & 27 & 25 \\
Kategori & A & B & A \\
\hline
\end{tabular}

Data hasil penilaian siswa mengenai kepraktisan perangkat diperoleh dengan menggunakan lembar penilaian siswa. Lembar penilaian siswa ini digunakan untuk mengetahui penilaian siswa terhadap kepraktisan perangkat LKS yang diberikan kepada seluruh siswa setelah selesai pelaksanaan uji coba. Data hasil penilaian siswa tersebut disajikan pada Tabel 7. 
Tabel 7. Hasil Analisis Penilaian Siswa terhadap LKS

\begin{tabular}{lcl}
\hline No & Siswa Sekolah & LKS \\
\hline 1 & SMK N 6 Jurusan AP1 & 2049 \\
& Skor Total & 2049 \\
& Rata-rata & 64,03 \\
& Kategori & A \\
\hline
\end{tabular}

Selain itu, observasi terhadap keterlaksanaan pembelajaran juga dilakukan pada setiap pertemuan dan bertujuan untuk mengetahui kepraktisan perangkat pembelajaran yang dikembangkan. Persentase keterlaksanaan pembelajaran pada setiap pertemuan disajikan pada Tabel 8.

Tabel 8. Persentase Observasi Keterlaksanaan Pembelajaran pada Setiap Pertemuan

\begin{tabular}{|c|c|c|c|c|c|}
\hline \multicolumn{4}{|c|}{ Skor Pada Pertemuan ke } & \multirow{2}{*}{ Rata-rata } & \multirow{2}{*}{ Kategori } \\
\hline 1 & 2 & 3 & 4 & & \\
\hline 80 & 90 & 95 & 97,5 & 90,625 & Praktis \\
\hline
\end{tabular}

Berdasarkan Tabel 8, keterlaksanaan pembelajaran dengan pendekatan saintifik telah melebihi kriteria minimal yang harus dicapai $(80 \%)$ yaitu $90,625 \%$. Selain itu juga, lembar penilaian dari guru dan siswa menunjukkan bahwa perangkat pembelajaran yang dihasilkan mencapai kategori sangat praktis. Dengan demikian dapat disimpulkan bahwa perangkat yang dikembangkan memenuhi kriteria kepraktisan. Kepraktisan perangkat pembelajaran ini didukung oleh penyusunan perangkat pembelajaran yang disesuaikan dengan tahapan-tahapan pendekatan saintifik oleh Hosnan (2014, p.34).

Selain itu melihat kepraktisan perangkat, pelaksanaan uji coba lapangan juga bertujuan untuk mengukur keefektifan perangkat yang dikembangkan melalui data yang diperoleh. Data keefektifan meliputi data tes hasil belajar dan data tes kemampuan komunikasi matematika. Tes prestasi belajar diberikan pada siswa setelah selesai proses pembelajaran untuk beberapa kompetensi dasar. Keefektifan perangkat pembelajaran dilihat dari presentase ketuntasan siswa secara klasikal yaitu $75 \%$ dari jumlah siswa dalam satu kelas telah memenuhi nilai kriteria ketuntasan minimal (KKM).

Tabel 9. Data Tes Kemampuan Komunikasi Matematika

\begin{tabular}{lcccc}
\hline $\begin{array}{c}\text { Siswa } \\
\text { Kelas }\end{array}$ & $\begin{array}{c}\text { Nilai } \\
\text { rata- } \\
\text { rata }\end{array}$ & KKM & $\begin{array}{c}\text { Jumlah } \\
\text { siswa yang } \\
\text { mencapai } \\
\text { KKM }\end{array}$ & $\begin{array}{c}\text { Persentase } \\
\text { Ketuntasan }\end{array}$ \\
\hline $\mathrm{X} \mathrm{AP}$ & 80,16 & $\geq 75$ & 25 & $78,125 \%$ \\
\hline
\end{tabular}

Berdasarkan Tabel 9 terlihat persentase ketuntasan siswa kelas X AP adalah 78,125\%. Hasil analisis data tersebut menunjukkan bahwa banyak siswa yang mencapai KKM pada kelas $\mathrm{X}$ AP lebih dari $75 \%$. Sehingga dapat disimpulkan bahwa perangkat pembelajaran yang dikembangkan telah mencapai kriteria efektif.

\section{Pembahasan}

Kemampuan komunikasi matematika adalah salah satu kemampuan yang perlu untuk dikembangkan dalam pembelajaran matematika, karena melalui kemampuan ini siswa dilatih untuk mengemukakan permasalahan-permasalahan yang dialami kepada teman dan guru, sehingga akan memperoleh solusi dan jalan keluar. Hal tersebut senada dengan pernyataan Pugalee (2001, p.3) yang mengatakan bahwa siswa perlu dibiasakan dalam pembelajaran untuk memberikan argumen atas setiap jawabannya serta memberikan tanggapan atas jawaban yang diberikan oleh orang lain, sehingga apa yang sedang dipelajari menjadi lebih bermakna baginya.

Komponen yang penting dalam pelaksanaan pembelajaran matematika adalah perangkat pembelajaran. Akan tetapi saat ini yang masih menjadi hambatan yaitu keterbatasan perangkat pembelajaran matematika yang berorientasi pada kemampuan komunikasi matematika siswa secara lengkap, baik dari RPP, LKS dan TPB, khususnya untuk SMK Kepariwisataan.

Salah satu pendekatan yang digunakan dalam pembelajaran Kurikulum 2013 adalah pendekatan saintifik. Pendektan ini memudahkan guru atau pengembang kurikulum untuk memperbaiki proses pembelajaran, yaitu dengan memecah proses ke dalam langkah-langkah atau tahapan-tahapan secara terperinci yaitu mengamati, menanya, mencoba, mengasosiasi, dan mengomunikasikan yang didalamnya memuat instruksi untuk siswa melaksanakan kegiatan pembelajaran. Hal ini sesuai dengan pernyataan dari Varelas \& Ford (2008, p.31).

Kurikulum 2013 memasukan materi limit fungsi aljabar sebagai materi yang baru bagi SMK kepariwisataan. Hal ini membuat perangkat pembelajaran yang dikembangkan menjadi sangat bermanfaat bagi guru SMK kepariwisataan.

Berdasarkan tahap pendefinisisan, penelitian ini mengembangkan perangkat pembelajaran limit fungsi aljabar untuk kelas X SMK Kepariwisataan (RPP, LKS dan TPB) dengan 
pendekatan saintifik yang berorientasi pada kemampuan komunikasi matematika siswa. Kelayakan dari produk akhir berupa perangkat pembelajaran limit fungsi aljabar dengan menggunakan pendekatan saintifik yang berorientasi pada kemampuan komunikasi siswa yang ditinjau dari tiga hal yaitu kevalidan, kepraktisan dan keefektifan.

Berdasarkan hasil validasi yang dilakukan oleh ahli yang berkompeten maka diperoleh masukan dan saran agar produk yang dikembangkan mencapai kriteria valid. Setelah melakukan revisi yang sesuai dengan saran dan masukan validator, maka produk perangkat pembelajaran yang dihasilkan (RPP, LKS dan TPB) dinyatakan telah mencapai kriteria valid berdasarkan hasil validasi beberapa ahli. Kevalidan perangkat pembelajaran didukung oleh penyusunan perangkat yang sesuai dengan Kurikulum 2013.

Berdasarkan hasil uji coba lapangan dapat diketahui bahwa perangkat pembelajaran yang dihasilkan telah mencapai kategori sangat praktis. Kepraktisan diukur berdasarkan penilaian guru dan siswa serta observasi keterlaksanaan pembelajaran. Keterlaksanaan pembelajaran dengan pendekatan saintifik telah melebihi kriteria minimal yang harus dicapai $(80 \%)$ yaitu $90,625 \%$. Selain itu juga, hasil penilaian dari guru dan siswa juga menunjukkan bahwa perangkat pembelajaran yang dihasilkan mencapai kategori sangat praktis. Kepraktisan perangkat pembelajaran ini didukung oleh penyusunan perangkat pembelajaran yang disesuaikan dengan tahapan-tahapan pendekatan saintifik oleh Hosnan (2014, p. 34).

Selain itu, berdasarkan hasil uji coba lapangan dapat diketahui bahwa perangkat pembelajaran yang dihasilkan telah mencapai kriteria efektif. Perangkat pembelajaran dikatakan efektif jika hasil tes prestasi belajar dan hasil tes kemampuan komunikasi siswa telah memenuhi kriteria ketuntasa belajar secara klasikal yaitu minimal 75\%. Hasil dari analisis TPB menunjukkan bahwa persentase ketuntasan klasikal siswa pada kelas yang diteliti adalah lebih dari $75 \%$. Berdasarkan hal tersebut, dapat disimpulkan bahwa perangkat pembelajaran limit fungsi aljabar yang dikembangkan memenuhi kriteria efektif. Hal ini juga mengindikasikan bahwa pemahaman siswa terhadap matematika sudah cukup baik. Capaian tersebut sejalan dengan pendapat Brodie (2010) yang menyatakan bahwa pemahaman terhadap matematika diasumsikan melalui komunikasi matematis.

\section{SIMPULAN DAN SARAN}

\section{Simpulan}

Berdasarkan hasil penelitian dan pembahasan diperoleh kesimpulan sebagai berikut: (1) produk perangkat pembelajaran matematika siswa SMK yang terdiri atas RPP, LKS, dan TPB memenuhi kriteria valid; (2) produk perangkat pembelajaran matematika siswa SMK yang terdiri atas RPP, LKS, dan TPB setelah melalui tahap akhir uji coba lapangan memenuhi kriteria praktis; (3) produk perangkat pembelajaran matematika siswa SMK yang terdiri atas RPP, LKS dan TPB memenuhi kriteria efektif ditinjau dari prestasi dan kemampuan komunikasi matematis siswa. Keefektifan produk terlihat dari perolehan hasil TPB siswa yang dijadikan subjek uji coba menunjukkan bahwa $\geq$ $75 \%$ siswa telah mencapai KKM dan lebih dari $\geq 75 \%$ siswa telah mencapai KKM untuk kemampuan komunikasi matematika.

\section{Saran}

Beberapa saran untuk pemanfaatan, diseminasi dan pengembangan produk lebih lanjut yaitu: (1) perangkat pembelajaran matematika siswa SMK yang dihasilkan terdiri atas RPP, LKS dan TPB telah memenuhi kriteria valid, praktis dan efektif, sehingga layak dimanfaatkan untuk pembelajaran di kelas; (2) produk perangkat pembelajaran yang dihasilkan dapat dijadikan referensi dan bahan masukan bagi para guru dalam menyusun perangkat pembelajaran matematika dengan menggunakan pendekatan saintifik yang berorientasi pada prestasi belajar dan kemampuan komunikasi matematika siswa SMK yang akan digunakan pada pembelajaran di kelas.

\section{DAFTAR PUSTAKA}

Aragon, A. (2007). Girth control. The science of fat loss and muscle Gain. Alan Aragon Publishing.

Azwar, S. (2009). Penyusunan skala psikologi. Yogyakarta: Pustaka Pelajar.

Brodie, K. (2010). Teaching mathematical reasoning in secondary school classroom. London: Springer.

Cai, J., Lane, S. \& Jakabcsin, M. S. (1996). The role of open ended tasks and holistic scoring rubrics: Assesing student' mathematical reasoning communication. Reston, VA: NCTM 
Cooke, B. D., \& Buchholz, D. (2005). Mathematical communication in the classroom: a teacher makes a difference. Early Childhood Education Jurnal, 32(6), 365-369. Retrive from: http:// http://link.springer.com/ article/10.1007/s10643-005-0007-5

Daryanto, dkk. (2014). Pengembangan perangkat pembelajaran. Yogyakarta: Gava Media

Dyer, J. et al. (2011). The innovators DNA. Boston, MA: Harvard Business Review Press

Eggen P., \& Kaucak, D. (2012). Strategi dan model pembelajaran (mengajarkan kontent dan ketrampilan berpikir). (Terjemahan Satrio Wahono). Boston, MA: Pearson Education.

Greenes, C. \& Schulman, L. (1996). Communication processes in mathematical explorations and investigations. Dalam P. C. Elliot \& M. J. Kennedy (Eds.), 1996 yearbook: Communication in mathematics, K-12 and beyond (pp. 159-169). Reston, Va.: NCTM.

Hosnan. (2014). Pendekatan saintifik dan kontekstual dalam pembelajaran abad 21. Bogor: Ghalia Indonesia

Johnson, R. L. et al. (2009). Assesing performance: Designing, scoring, and validating performance task. New York: Guilford.

Kemp. J. E., Morrison, G. R \& Ros, S. M. (1994). Designing effective instruction. New York: Macmillan College Publishing Company.

Kusnaeni, K., \& Retnawati, H. (2013). Problem posing dalam setting kooperatif tipe TAI ditinjau dari kemampuan komunikasi dan pemecahan masalah. PYTHAGORAS: Jurnal Pendidikan Matematika, 8(1), 3343.

doi:http://dx.doi.org/10.21831/pg.v8i1.84 92

Kyriacou, C. (2009). Effective teaching in school: Theory and practice. Third edition. London: Nelson Thornes
Moon, B., Meyes, A. S., \& Hutchinson, S. (2002). Teaching, learning and the curriculum in secondary school. New York: Routledge Falmer

National Council of Teachers of Mathematics (2000). Principles and standars for school mathematics. Reston, VA: NCTM.

Nazarudin. (2007). Manajemen pembelajaran, implementasi konsep, karakteristik dan metodologi agama Islam di sekolah umum. Yogyakarta: Teras.

OECD. (2014). PISA 2012 Results: what students know and can do - student performance in mathematics, reading and science (Volume 1, Revised Edition, February 2014). PISA: OECD Publishing.

Posamentier, A. S., Jaye, D., \& Krulik, S. (2007). Exemplary practices for secondary math teachers. Alexandria, VA: ASCD.

Pugalee, D. K. (2001). Using communication to develop students' mathematical literacy. Journal Mathematics Teaching in the Middle School, 6(5), 296-299.

Rahmawati ES, Y., \& Harta, I. (2014). Keefektifan pendekatan open-ended dan ctl ditinjau dari hasil belajar kognitif dan afektif. Jurnal Riset Pendidikan Matematika, $\quad 1(1), \quad 113-126$. doi:http://dx.doi.org/10.21831/jrpm.v1i1. 2669

Sutherland, R. (2007). Teaching for learning mathematics. New York: Mc Graw Hill.

Thiagarajan S., Semmel D., \& Semmel, M. I. (1974). Instructional development for training teachers of exceptional children: A sourcebook. Minneapolis, MA: Central for Innovation on Teaching the Handicaped.

Varelas, M., \& Ford, M. (2009). The scientific method and scientific inquiry: Tensions in teaching and learning. Journal Science Education, 94, 29-47

Wilder, S. J., et al. (Eds.). (2011). Learning to teach mathematics in the secondary school: a companion to school experience $\left(3^{\text {rd }}\right.$ ed). Abingdon, Oxon: Routledge.

Winkel, W. S (2014). Psikologi pengajaran. Jakarta: Gramedia 